Supporting Information: Kopp et al.

\title{
Peptide Macrocyclization: The Reductase of the Nostocyclopeptide Triggers the Self-Assembly of a Macrocyclic Imine
}

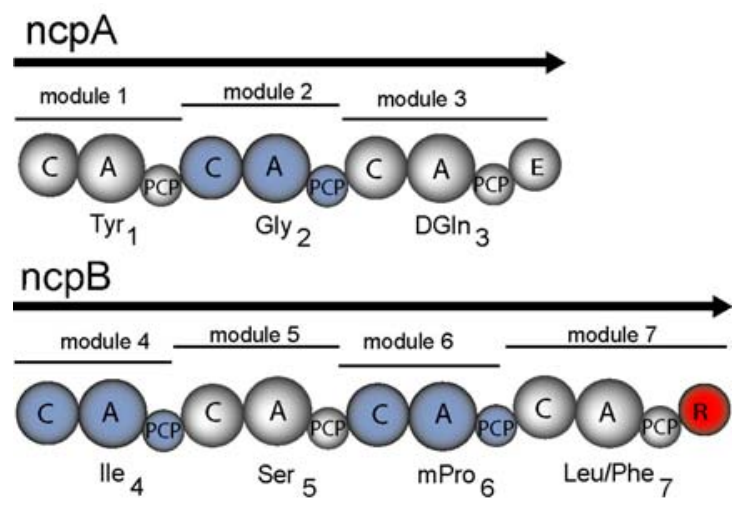

Figure S1. The nostocyclopeptide NRPS consists of two subunits, ncpA and ncpB. Following the linearity rule, seven modules are responsible for the incorporation of seven amino acids. Instead of the commonly found thioesterase domain an R domain (highlighted in red) is found at the Cterminal position of ncpB.

Gene Synthesis, Cloning and Expression of Nostocyclopeptide PCP-R and Nostocyclopeptide R. The nostocyclopeptide gene fragment ncp PCP-R, flanked by BamHI and NotI restriction sites, was synthesized via solid phase oligonucleotide synthesis (EZBiolab). Ncp $R$ was amplified from the synthetic DNA by polymerase chain reaction (PCR) with Pfu polymerase (Stratagene) and the following oligonucleotides: 5'-AAA AAA GGA TCC ATG GAC CAC GAA AGC CTG CAC AGC ACC C-3' and 5'-AAA AAA GCG GCC GCT TAG CGT CGG GGG GCG AGT CGC C-3’. The synthetic gene fragment and the PCR product were cloned into the BamHI/NotI restriction sites of a derivatized pQE60 vector (Qiagen), which appends an Nterminal heptahistidine tag to the expressed protein. For preparation of the recombinant plasmids E. coli Top10 cells (Novagen) was used. The identity of the constructs was confirmed by DNA sequencing performed by GATC biotech on an ABI prism 310 genetic analyzer (Applied Biosystems).

Recombinant proteins were overproduced in E. coli BL21 cells (Novagen) yielding in $6 \mathrm{mg} / \mathrm{L}$ culture ncp PCP-R and $5 \mathrm{mg} / \mathrm{L}$ culture ncp R, respectively (Novagen). The transformed cells were grown at $30{ }^{\circ} \mathrm{C}$ to $\mathrm{OD}=0.5(600 \mathrm{~nm})$, induced with $0.5 \mathrm{mM}$ IPTG, and again grown at 25 ${ }^{\circ} \mathrm{C}$ for another $4.5 \mathrm{~h}$. The recombinant proteins were purified by Ni-NTA affinity chromatography (Amersham Pharmacia Biotech). Dialysis into $25 \mathrm{mM}$ Hepes, $50 \mathrm{mM} \mathrm{NaCl}, \mathrm{pH}$ 7.0 was carried out using HiTrap Desalting columns (Amersham Pharmacia Biotech). The concentration of the purified proteins was determined spectrophotometrically using the calculated extinction coefficient (ncp PCP-R $1.11 \mathrm{~mol}^{-1} \mathrm{dm}^{3} \mathrm{~cm}^{-1}$; ncp R $0.80 \mathrm{~mol}^{-1} \mathrm{dm}^{3} \mathrm{~cm}^{-1}$ ) at $280 \mathrm{~nm}$. After flash freezing in liquid nitrogen the proteins were stored at $-80{ }^{\circ} \mathrm{C}$. 
Supporting Information: Kopp et al.

\section{Peptide Macrocyclization: The Reductase of the Nostocyclopeptide Triggers the Self-Assembly of a Macrocyclic Imine}

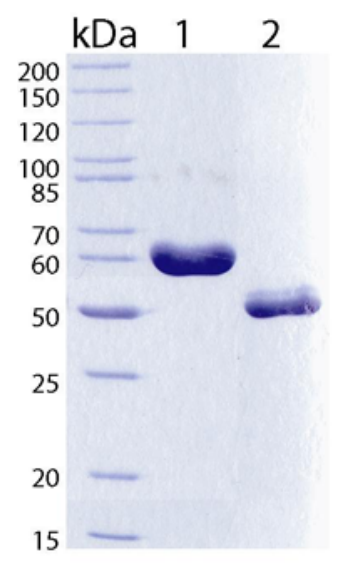

Figure S2. Coomassie stained SDS-PAGE of purified recombinant ncp PCP-R (lane 1, $58.6 \mathrm{kDa}$ ) and ncp R (lane 2, $48.6 \mathrm{kDa}$ ).

Synthesis of Peptidyl-Thioester Substrates. All linear peptides were produced by solid phasepeptide synthesis as described previously. ${ }^{1}$ Peptide synthesis was carried out on an Advanced ChemTech APEX 396 synthesizer (0.1 mmol scale). Protected amino acids and 2-chlorotritylresin were purchased from Novabiochem, coupling reagents from Sigma-Aldrich. After cleavage from the solid support, side chain protected peptides were activated at the C-terminus as thioesters.

Synthesis of peptidyl-CoA substrates: 2 equiv of coenzyme A trilithium salt (mp biomedicals), 1.5 equiv PyBOP, and 4 equiv of potassium carbonate were added to 1 equiv of side chain protected peptide and dissolved in a 1:1 THF/water mixture. The reaction mixture was stirred at room temperature for $3 \mathrm{~h}$, frozen in liquid nitrogen and lyophilized over night. The acid-labile side-chain protecting groups were cleaved by using trifluoroacetic acid, triisopropylsilane, and $\mathrm{H}_{2} \mathrm{O}$ (95/2.5/2.5). After incubation for 20 min the deprotected peptides were precipitated in $30 \mathrm{~mL}$ ice cold ether.

Synthesis of peptidyl-ppan substrates: Phosphopantetheine (ppan) was prepared as described previously. ${ }^{2}$ One equivalent of coenzyme A, 0.2 equiv of TCEPxHCl, and $0.5 \mathrm{unit} / \mu \mathrm{mol}$ nucleotide pyrophosphatase (Sigma) were dissolved in HEPES-buffer (50 mM, pH 7.5). After incubation at $30{ }^{\circ} \mathrm{C}$ for $18 \mathrm{~h}$ the mixture was lyophilized. For the preparation of peptidyl-ppan substrates 1.5 equiv of ppan, 1.5 equiv of PyBOP, and 4 equiv of potassium carbonate were added to 1 equiv of the side chain protected peptide and dissolved in a 1:1 THF/water mixture. The reaction mixture was stirred for $2 \mathrm{~h}$ at room temperature and the solvent was removed.

Synthesis of peptidyl-SNAC substrates: The synthesis of peptidyl-SNAC substrates was reported previously. ${ }^{3}$ Briefly, 10 equiv SNAC, 2 equiv DCC and 2 equiv $\mathrm{HOBTxH}_{2} \mathrm{O}$ were added to 1 equiv of the side chain protected peptide and dissolved in DCM. After $30 \mathrm{~min}$ a catalytic amount $\mathrm{K}_{2} \mathrm{CO}_{3}$ was added and stirring was continued for $2.5 \mathrm{~h}$. The solvent was removed by rotary evaporation and side chain groups were removed as reported above.

Synthesis of peptidyl-SPh substrates: The synthesis of peptidyl-thiophenol derivatives was carried out following the protocol for peptidyl-SNACs using 10 equiv thiophenol instead of SNAC.

Purification of the deprotected peptidyl-thioesters was carried out on an Agilent 1100 semipreparative HPLC system with a reversed-phase 250/21 Nucleodur 100-5 C18ec column 
Supporting Information: Kopp et al.

\section{Peptide Macrocyclization: The Reductase of the Nostocyclopeptide Triggers the Self-Assembly of a Macrocyclic Imine}

(Macherey and Nagel). For the peptidyl-CoA and peptidyl-ppan derivatives a gradient from 5$55 \%$ of $0.1 \%$ TFA/acetonitrile in $0.1 \%$ TFA/water was applied over $30 \mathrm{~min}\left(20 \mathrm{ml} / \mathrm{min}, 25{ }^{\circ} \mathrm{C}\right)$. For the peptidyl-SNAC and peptidyl-thiophenol derivatives the gradient was adapted as follows: $10-70 \%$ of $0.1 \%$ TFA/acetonitrile in $0.1 \%$ TFA/water was applied over $30 \mathrm{~min}(20 \mathrm{ml} / \mathrm{min}, 45$ $\left.{ }^{\circ} \mathrm{C}\right)$. The obtained products were dissolved in DMSO to a final concentration of $10 \mathrm{mM}$ and identity was confirmed by high-performance liquid chromatography-mass spectrometry (HPLCMS; Table S1).
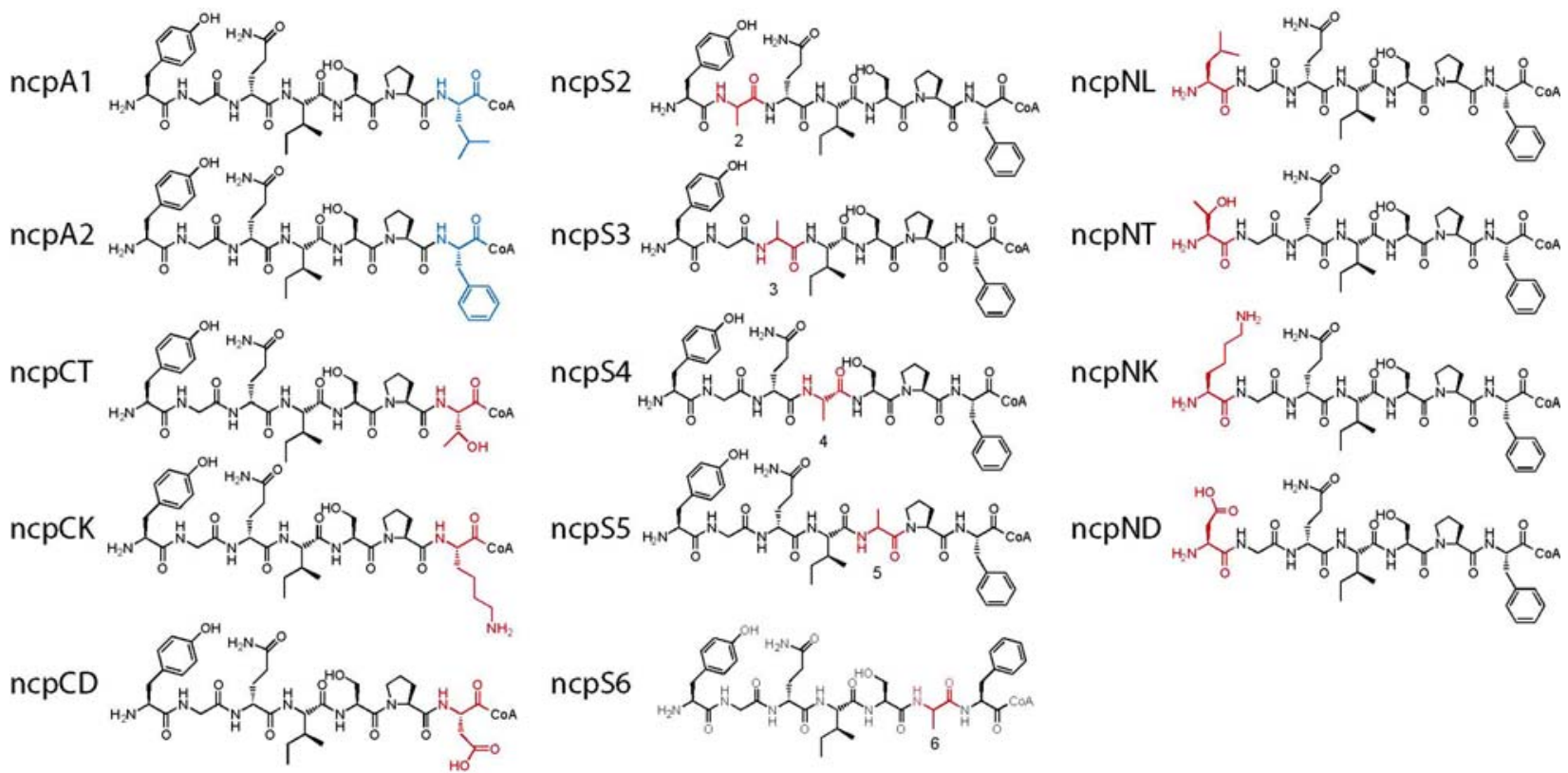

Figure S3. Peptidyl-CoA substrates used in this study: Naturally occurring C-termianl amino acids are highlighted in blue. Substitutions made to investigate imine macrocyclization are highlighted in red.

\begin{tabular}{ccc}
\hline Compound & $\begin{array}{c}\text { Calculated Mass } \\
{[\mathbf{M}+\mathbf{H}]^{+}[\mathbf{D a}]}\end{array}$ & $\begin{array}{c}\text { Observed Mass } \\
{[\mathbf{M}+\mathbf{H}]^{+}[\mathbf{D a}]}\end{array}$ \\
\hline ncpA1 & 1526.5 & 1526.3 \\
$\mathbf{n c p A 2}$ & 1560.5 & 1560.4 \\
ncpCT & 1514.5 & 1514.6 \\
ncpCK & 1541.5 & 1541.5 \\
ncpCD & 1528.5 & 1528.5 \\
ncpS2 & 1573.5 & 1573.6 \\
ncpS3 & 1503.5 & 1503.4 \\
ncpS4 & 1518.5 & 1518.4 \\
ncpS5 & 1544.5 & 1544.3 \\
ncpS6 & 1534.5 & 1534.6 \\
ncpNL & 1510.5 & 1510.6 \\
ncpNT & 1498.5 & 1498.6 \\
ncpNK & 1525.5 & 1525.5
\end{tabular}


Supporting Information: Kopp et al.

\section{Peptide Macrocyclization: The Reductase of the Nostocyclopeptide Triggers the Self-Assembly of a Macrocyclic Imine}

\begin{tabular}{ccc} 
ncpND & 1512.5 & 1512.6 \\
ncpA1-ppan & 1151.5 & 1151.6 \\
ncpA2-ppan & 912.4 & 912.5 \\
ncpA1-SNAC & 1117.5 & 1117.6 \\
ncpA2-SNAC & 878.4 & 878.5 \\
ncpA1-SPh & 903.4 & 902.8 \\
ncpA2-SPh & 869.4 & 869.4 \\
\hline
\end{tabular}

Table S1. Characterization of peptidyl-thioester substrates by ESI-MS.

Synthesis of peptide aldehydes. For the synthesis of peptide aldehydes H-Thr-Gly-NovaSyn ${ }^{\circledR}$ TG resin (Novabiochem) was used, preloaded with leucin or phenylalanine amino aldehydes respectively. The resin was suspended in DMF and left swelling for $30 \mathrm{~min}$ and was then suitable for Fmoc protocols as used for the preparation of the peptidyl-thioesters. After assembly of the target sequence protecting groups were removed by treatment with 100\% TFA (2x10 min). The resin was washed then with DCM and the product was cleaved from the resin by treatment with AcOH/water/DCM/MeOH (10:5:63:22) for 30 min to obtain the deprotected peptide aldehyde. Purification of the crude product was carried out following the above described protocol for peptidyl-CoA derivatives. The purified product was dissolved in DMSO to a final concentration of $10 \mathrm{mM}$.

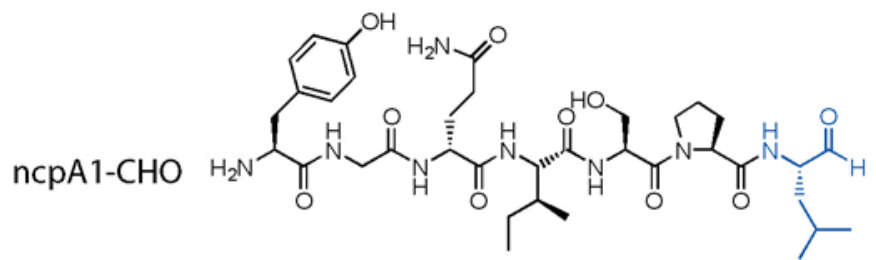<smiles>CCC(C)C(NC(=O)C(CCC(N)=O)NC(=O)CNC(=O)C(N)Cc1ccc(O)cc1)C(=O)NC(CO)C(=O)N1CCCC1C(=O)N[C@@H](C=O)Cc1ccccc1</smiles>

Figure S4. Peptide aldehydes synthesized for this study.

\begin{tabular}{ccc}
\hline Compound & $\begin{array}{c}\text { Calculated Mass } \\
{[\mathbf{M}+\mathbf{H}]^{+}[\mathbf{D a}]}\end{array}$ & $\begin{array}{c}\text { Observed Mass } \\
{[\mathbf{M}+\mathbf{H}]^{+}[\mathbf{D a}]}\end{array}$ \\
\hline ncpA1-CHO & 761.4 & 761.4 \\
ncpA2-CHO & 795.4 & 795.4 \\
\hline
\end{tabular}

Table S2. Characterization of peptide-aldehydes by ESI-MS. 
Supporting Information: Kopp et al.

\section{Peptide Macrocyclization: The Reductase of the Nostocyclopeptide Triggers the Self-Assembly of a Macrocyclic Imine}

Enzyme Assays. Enzyme assays with the peptidyl-thioester derivatives were carried out in a total volume of $100 \mu \mathrm{L}$ containing $20 \mu \mathrm{M}$ ncp PCP-R or ncp R, $250 \mu \mathrm{M}$ peptidyl-CoA substrate, 1.5 mM NADPH, $10 \mathrm{mM} \mathrm{MgCl}_{2}$, and $10 \mu \mathrm{M} \mathrm{MnCl}_{2}$ in $50 \mathrm{mM} \mathrm{HEPES,} 50 \mathrm{mM} \mathrm{NaCl}$ at $\mathrm{pH}$. All assays were incubated at $25{ }^{\circ} \mathrm{C}$ for $1 \mathrm{~h}$. The reactions were stopped by the addition of $1 \mathrm{~mL}$ $\mathrm{MeOH}$ and stored at $-20{ }^{\circ} \mathrm{C}$ for $1 \mathrm{~h}$. The supernatant was separated from the precipitant by centrifugation for $15 \mathrm{~min}$ at maximum speed. After removing the solvent under vacuum at $30{ }^{\circ} \mathrm{C}$, the remaining pellet was resuspended in $100 \mu \mathrm{L} 10 \%$ acetonitril in water and analyzed by LCMS on a C18 Nucleodur column (Macherey and Nagel, 125/2 pore diameter of $100 \AA \AA$, particle size of $3 \mu \mathrm{m}$ ) with the following gradient: $10-80 \%$ acetonitrile in water over 25 min at 0.2 $\mathrm{mL} / \mathrm{min}$ and $45^{\circ} \mathrm{C}$. It was crucial that TFA was not added to the solvents as a modifying agent, as the low $\mathrm{pH}$ would destruct the macrocyclic imine. Further, NADH was not accepted as electron donor instead of NADPH.

\begin{tabular}{ccc}
\hline Compound & $\begin{array}{c}\text { Macrocyclic Imine } \\
{[\mathbf{M}+\mathbf{H}]^{+}[\mathbf{D a}]}\end{array}$ & $\begin{array}{c}\text { Peptide-Aldehyde } \\
{\left[\mathbf{M}+\mathbf{H}^{+}[\mathbf{D a}]\right.}\end{array}$ \\
\hline ncpS2 & $790.4(790.4)$ & $808.4(808.4)$ \\
ncpS3 & $720.3(720.4)$ & $738.4(738.4)$ \\
ncpS4 & $735.4(735.4)$ & n.d \\
ncpS5 & $761.4(761.4)$ & n.d \\
ncpS6 & $751.5(751.4)$ & n.d
\end{tabular}

Table S3. Results of the alanine-scanning experiment with masses of the observed products. Calculated masses are given in brackets. N.d. = not detected.

\begin{tabular}{ccc}
\hline Compound & $\begin{array}{c}\text { Macrocyclic Imine } \\
{[\mathbf{M}+\mathbf{H}]^{+}[\mathbf{D a}]}\end{array}$ & $\begin{array}{c}\text { Peptide-Aldehyde } \\
{[\mathbf{M}+\mathbf{H}]^{+}[\mathbf{D a}]}\end{array}$ \\
\hline ncpCT & $731.4(731.4)$ & n.d \\
ncpCK & n.d & $776.4(776.4)$ \\
ncpCD & n.d & $763.4(763.4)$ \\
ncpNT & $715.5(715.6)$ & n.d \\
ncpNK & n.d & $760.2(761.4)$ \\
ncpND & n.d & $747.5(747.7)$ \\
ncpNL & $727.4(727.4)$ & n.d \\
\hline
\end{tabular}

Table S4. Results of C- and N-terminal substitutions with masses of the observed products. Calculated masses are given in brackets.

For the imine cyclization assay $50 \mu \mathrm{M}$ peptide aldehyde were incubated in a total volume of 100 $\mu \mathrm{L}$ containing $50 \mathrm{mM} \mathrm{NaCl}, 50 \mathrm{mM}$ Hepes at $\mathrm{pH} 6$ for $2 \mathrm{~h}$ at $25^{\circ} \mathrm{C}$. For the cyclization assay with enzyme $5 \mu \mathrm{M}$ ncp PCP-R was added to the reaction mixture. Assays were stopped and analyzed as reported above. 
Supporting Information: Kopp et al.

\section{Peptide Macrocyclization: The Reductase of the Nostocyclopeptide Triggers the Self-Assembly of a Macrocyclic Imine}
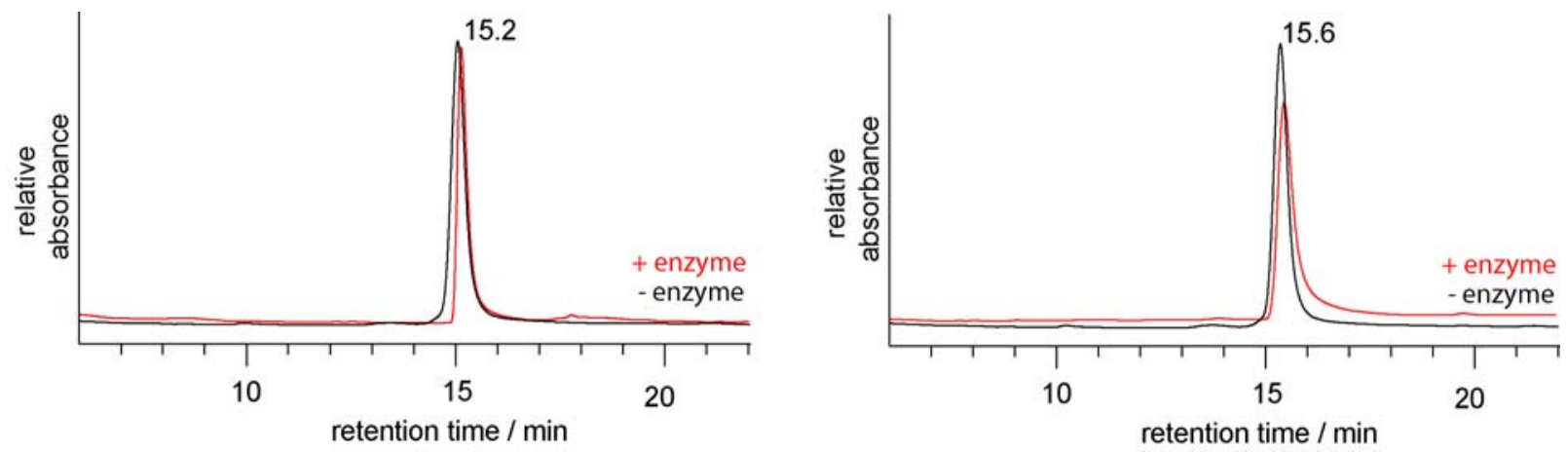

Figure S5. Cyclization assay with the peptide-aldehyde ncpA1-CHO and ncpA2-CHO. The formation of the macrocyclic imines ncpA1 $\left(\mathrm{t}_{\mathrm{R}}=15.6 \mathrm{~min} ;[\mathrm{M}+\mathrm{H}]^{+}=777.393\right)$ and $\mathrm{ncp} A 2\left(\mathrm{t}_{\mathrm{R}}=15.2\right.$ min; $\left.[\mathrm{M}+\mathrm{H}]^{+}=743.401\right)$ is not dependent on the ncp PCP-R.

Photometric Determination of Kinetic Parameters. For kinetic studies the assay was carried out as described above and followed spectrophotometrically (Pharmacia Ultrospec 3100 pro UV/Visible spectrophotometer). This direct monitoring is possible, because the reduction of each peptide-thioester substrate consumes one equivalent NADPH leading to a decrease in absorption at $340 \mathrm{~nm}$. Following the extinction coefficients $6220 \mathrm{M}^{-1} \mathrm{~cm}^{-1}$ for NADPH $\mathrm{K}_{\mathrm{M}}$ and $\mathrm{k}_{\mathrm{cat}}$ values for the reduction reaction were determined.

\begin{tabular}{cccc}
\hline Substrate & $\mathbf{K}_{\mathbf{M}}(\mu \mathbf{M})$ & $\mathbf{k}_{\text {cat }}\left(\mathbf{m i n}^{-\mathbf{1}}\right)$ & $\mathbf{k}_{\mathbf{c a t}} / \mathbf{K}_{\mathbf{M}}\left(\mathbf{m i n}^{-\mathbf{1}} \mathbf{m} \mathbf{M}^{-\mathbf{1}}\right)$ \\
\hline ncpA1 & 101 & 9 & 89 \\
ncpA2 & 102 & 6 & 59 \\
\hline
\end{tabular}

Standard Error: $\pm 15 \%$

Table S5. Kinetic Parameters for recombinant ncp PCP-R.

\section{References}

(1) Kohli, R. M.; Trauger, J. W.; Schwarzer, D.; Marahiel, M. A.; Walsh, C. T. Biochemistry 2001, 40, 7099-7108.

(2) Marshall, C. G.; Burkart, M. D.; Meray, R. K.; Walsh, C. T. Biochemistry 2002, 41, 84298437.

(3) Sieber, S. A.; Tao, J.; Walsh, C. T.; Marahiel, M. A. Angew Chem Int Ed Engl 2004, 43, 493-498. 